\title{
Dendrochronology of pedunculate oak (Quercus robur L.) in an old-growth pollarded woodland in northern Spain: establishment patterns and the management history
}

\author{
Vicente ROZAS ${ }^{\mathrm{a}, \mathrm{b} *}$ \\ a Departamento de Biología de Organismos y Sistemas, Universidad de Oviedo, Catedrático Rodrigo Uría, 33071 Oviedo, Spain \\ b Present address: Departamento de Ecología, Centro de Investigaciones Forestales y Ambientales de Lourizán, \\ Carretera a Marín km 4, Apartado 127, 36080 Pontevedra, Spain
}

(Received 13 November 2003; accepted 19 April 2004)

\begin{abstract}
Long-term patterns of tree establishment and past management practices, in an old-growth pollarded woodland in northern Spain, were studied using dendrochronological techniques. Age distribution revealed three main cohorts of pedunculate oak (Quercus robur L.): $<50$ years, 150-200 years old, and 250-500 years old. Juveniles and trees 200-299 years were found to be clumped and spatially segregated from older trees. Oaks older than 300 years showed a random spatial distribution. Mean pollarding intervals had increased through time, and the mean number of suppressions per year had decreased significantly. Pollarding frequency and intensity had decreased since 1917 in mature trees, and since 1905 in old-growths, suggesting a decline of the pollarding practice in the early 20th century. A delay of 6 years in growth releases, with respect to growth suppressions, was common. This resulted from both strong growth recovery after pollarding, and the release of growing space in the canopy. Mature oaks mainly showed 1-3 pollarding signals, while in old-growths between 4-7 growth suppressions per tree were more frequent. In 1774, 1792, 1806, 1839 and 1859, small groups of trees and scattered trees were pollarded, while in 1905 a generalised reduction of tree growth was noted. The results obtained from this study have significant connotations regarding the preservation and management of formerly pollarded woodlands.
\end{abstract}

dendroecology / kriging / ring width / spatial pattern / tree pollarding

Résumé - Dendrochronologie du chêne pédonculé (Quercus robur L.) dans un vieux bois traité en têtard dans le nord de l'Espagne : modèles d'installation et historique de la gestion. Des modèles à long terme d'installation des arbres et des pratiques de gestion passées ont été étudiées en utilisant les techniques dendrochronologiques, dans un vieux bois traité en têtard du nord de l'Espagne. La distribution des âges révèle trois principales cohortes de chênes pédonculés (Quercus robur L.) concernant l'âge des arbres : $<50$ ans, 150-200 ans et 250-500 ans. Les arbres jeunes et les arbres âgés de 200-299 ans étaient en bouquets et spatialement séparés des plus vieux arbres. Les chênes plus âgés que 300 ans montraient une distribution spatiale au hasard. La moyenne des intervalles d'étêtage s'est accrue au cours du temps et la moyenne des suppressions annuelles a décru significativement. La fréquence de l'étêtage et son intensité ont décru depuis 1917 pour les arbres mûrs et depuis 1905 pour les vieux arbres, suggérant un déclin des pratiques d'étêtage au début du $20^{\mathrm{e}}$ siècle. Un retard de 6 ans dans la reprise de croissance a été noté en relation avec la suppression des pousses. Ceci résulte ensemble du rétablissement d'une forte croissance après l'étêtage et de la reprise de croissance dans l'espace de la couronne. Les chênes matures montrent surtout 1-3 signaux d'étêtage, tandis que 4-7 suppressions par arbres étaient plus fréquentes chez les très vieux arbres. En 1774,1792, 1806,1839 et 1859, de petits groupes d'arbres et des arbres dispersés étaient étêtés, tandis qu'en 1905 une réduction générale de la croissance était notée. Les résultats de cette étude ont des connotations significatives conservant la préservation et la gestion des anciens bois traités en têtard.

dendroécologie / kriegeage / largeur des cernes / distribution spatiale / arbre traité en têtard

\section{INTRODUCTION}

Pollarding in wood-pastures is a traditional management system for broad-leaved forests. It has been in widespread use for centuries throughout Central and Western Europe [8, 38, $42]$. Grazed woodlands are usually composed of ancient trees that have grown in open spaces utilised for cattle pasture. These areas were traditionally used as a source of pasturage, fuel, timber and other forest products. Wood for lumber or charcoal was obtained by pollarding the tops of trees at a height of 2-3 m. Such trees responded by producing new crops of branch-wood out of reach of the animals. Trees regularly pollarded typically

\footnotetext{
* Corresponding author: vrozas.cifal@ siam-cma.org
} 
developed hollow trunks with large girths, and survived for a longer time than they would have in natural forests because of little competition from scattered neighbours [35].

The most extensive examples of pollarded wood-pasture in Europe are to be found in West Mediterranean woodlands. They are composed of diverse evergreen or deciduous oak species, which cover more than 3 million ha in the Iberian Peninsula [37]. The multiple agroforestry use of Mediterranean woodlands as pasture, source of acorns, fuel and cork, along with their partial cultivation, started in the Middle Ages. But this use was intensified in the late 19th century and the early 20th, when many natural forests were transformed in new wood-pastures [37]. By contrast, the area occupied by pollarded woodlands in the Atlantic and Central Europe have become progressively reduced since mediaeval times as a consequence of the abandonment of traditional management, the change of land use to create farmlands and imported tree plantations, or because of a natural transformation to a high forest structure [23, 35].

Some rare small fragments of pollarded wood-pastures remain in the Atlantic regions of Spain, usually due to their preservation in private parks, wooded commons or village greens. These infrequent populations of veteran pollards have great importance as havens for communities of saproxylic, epiphyte and mycorrhizal organisms rarely found in other habitats [17, $31,39]$. For these reasons, historical management practices, and tree life history in pollarded woodlands, should be investigated in order to design efficient future conservation policies focused on the maintenance of veteran pollards and the preservation of their special structure and ecological importance.

Dendrochronological techniques are considered to be the most useful and accurate tools in the investigation of past regeneration patterns, and in the reconstruction of disturbance history in temperate forests $[10,11,27,33,34]$. Tree-ring analysis has been used to reconstruct fire histories in woodlands [15, 51], to reproduce past forest insect infestations [21, 48], to study geomorphic processes [19,30], and to precisely date past earthquakes $[20,46]$. By contrast, dendrochronological studies, focused on past management reconstruction in manhandled forests, are rare [5, 9, 32]. Dendroarchaeological studies displayed abundant examples of pollarding signals in tree-rings [2, 3 , 13, 40]. However, dendrochronological techniques have never been used to reconstruct management systems over complete pollarded woodlands.

This work is a dendrochronological reconstruction of the management history in Tragamón, an old-growth oak woodland located in the Cantabrian lowlands, northern Spain. Past regeneration patterns, and historical management systems, were reconstructed based on tree locations and on increment cores obtained from intensive sampling. Standard procedures of treering analysis were adapted to determine the presence of pollarding signals in ring-widths. Specific objectives of the study were: (1) to investigate the temporal and spatial patterns of oak establishment, (2) to reconstruct the temporal variation in the frequency and intensity of growth suppressions and releases, (3) to estimate the temporal and spatial patterns of tree pollarding, and (4) to compare the reconstructed pollarding practices among separate oak age-classes.

\section{MATERIALS AND METHODS}

\subsection{Site description}

Tragamón is located near the city of Gijón ( $43^{\circ} 30^{\prime}$ N, $05^{\circ} 31^{\prime}$ W), on the coastal plain of Asturias, northern Spain. The soils are Hapludalfs on quaternary alluvial depositions of gravel, sand, and clay, with a geologic basement of Jurassic limestone and dolomite [14]. The climate is Atlantic, with a total annual precipitation of $980 \mathrm{~mm}$, and a mean annual temperature of $14{ }^{\circ} \mathrm{C}$. Tragamón is a 4.8 ha woodland mainly composed of pedunculate oak (Quercus robur L.), and some other native and introduced tree species, such as Acer pseudoplatanus L., Castanea sativa Mill., Fraxinus excelsior L., Ilex aquifolium L., Laurus nobilis L., Prunus laurocerasus L., Quercus pubescens Willd. and Taxus baccata $\mathrm{L}$. Five $C$. sativa trees are also old-growth pollards with massive, severely decomposed trunks and limbs. A road divide the park into two parts, here named as Northern Tragamón and Southern Tragamón (see Fig. 3). Southern Tragamón has been used as a recreation park since the 1960s, while access to Northern Tragamón was restricted up to 1992. At the north-east of Tragamón is La Isla park, composed of pollard and maiden pedunculate oaks. Tragamón constitutes a well-preserved example of formerly pollarded wood-pasture, a feature that has almost disappeared in the Atlantic Iberian Peninsula. Because of the aesthetic, historical, and environmental importance of ancient oaks, Tragamón was recently declared a Natural Monument by the regional authorities in Asturias.

\subsection{Sampling, ring-width measurement and tree-ring dating}

All living and dead trees ( $\mathrm{dbh} \geq 5 \mathrm{~cm}$ at $1.3 \mathrm{~m}$ above ground) were identified, labelled and measured. The spatial $x$ and $y$ co-ordinates of stem bases in Tragamón were measured using a GPS base station. Twenty-five percent of the area of La Isla was also surveyed, living and dead trees were identified, labelled and measured. The spatial coordinates of trees in La Isla were not measured. All labelled adult living oaks, without external evidence of bole rottenness, were cored with increment borers in autumn 2000. Totals of 52 mature oaks, all of them in La Isla, and 57 old-growth oaks, seven of them belonging to La Isla and 50 to Tragamón, were sampled for tree-ring analysis. Old-growth chestnut trees were not sampled because of severe bole rottenness. Since Tragamón is a protected area, only one core per tree was taken, $100 \mathrm{~cm}$ above ground level, in order to minimise the damage to the trees.

The cores were air-dried, glued onto wooden mounts and surfaced with a series of successively finer sandpaper grits. Tree-ring series were dated following standard procedures [47]. After preliminary dating, ring-widths were measured under magnification to the nearest $0.01 \mathrm{~mm}$ with a Velmex sliding-stage micrometer interfaced with a computer. Dating and measurement errors were corrected with the program COFECHA [18], which allowed additional, quantitative crossdating against a master site chronology. The master chronology was calculated from those ring-width series correctly synchronised and highly inter-correlated. In many cases quantitative crossdating allowed successful dating of the complete ring-width series. However, abrupt growth changes, found in the majority of the samples, made dating of many tree-ring series difficult, and synchronisation with the master chronology could not be definite in some tree-ring series that showed recurrent growth suppressions. In spite of this limitation, the estimated accuracy of the datings of pollarding signals in particular trees was over $2-3$ years.

\subsection{Tree age estimation}

In cores that showed the pith, tree age was estimated as the number of crossdated rings. In partial cores, which contained the arcs of the 
inner rings, the length of missing radii was calculated using a graphical method based on the convergence of xylem rays at the pith [44]. The number of missing rings was then estimated by extrapolating the radial growth rate from the innermost five rings in the cores. In partial cores, without the arcs of the inner rings, the length of missing radii was calculated as the difference between the bole geometric radius and the total core length. The number of missing rings was then estimated by extrapolating the mean radial growth rate from the innermost 20 rings in the cores [44]. Those trees that were not cored, and those from which unusable cores had been obtained, were aged from their diameters, using age-diameter equations calculated from cored trees. Equations were calculated for three different oak cohorts that showed non-overlapping age ranges, a procedure that provided more accurate age estimates than would have been obtained from equations based on the population as a whole [44]. Tree-age estimates, without any correction for the time taken to reach coring height, were summarised into age distributions at 25-year intervals.

\subsection{Spatial analysis}

To study the distribution of tree ages the spatial patterns of separate age classes were analysed using the nearest-neighbour technique [50]. Living oaks in Tragamón were arbitrarily classified into four age classes $(<50,200-299,300-399$ and 400-499 years) and the mean distance between target trees and their nearest neighbours was calculated within, and between, age classes. The null hypothesis of a random arrangement of ages among oak stems was tested using a bootstrap procedure $[28,29]$. Each previously calculated mean distance-to-thenearest-neighbour was compared with the mean distance expected under the null hypothesis. The expected distance was computed from bootstrap samples obtained by randomly distributing the ages of neighbouring trees among tree locations, taken at random and with replacement from the non-target trees. The significance of deviation from the null hypothesis was calculated as the proportion of bootstrap samples in which the expected mean distance was smaller than the observed mean, multiplied by two to effect a two-sided test [28]. The critical values, corresponding to the significance levels 0.05 and 0.01 , were obtained from 100 and 1000 bootstrap samples. A significant negative deviation was interpreted as evidence of aggregation, while a significant positive deviation indicated repulsion.

Ordination and clustering techniques are generally used to identify even-aged patches of trees [7]. These methods focus on the establishment of regions that are homogeneous with respect to tree age, but differing from spatially adjacent regions. On the other hand, kriging techniques use a local estimate of the ages of neighbouring trees, corrected to account for the global structure of age, to produce a detailed surface map of the spatial distribution of tree ages [25]. To describe the spatial structure of tree ages in Tragamón, a map of oak stems was plotted along with a surface map of 100-year-age nested isolines calculated by kriging.

\subsection{Tree-ring analysis}

In this work, an abrupt growth change was considered as those conspicuous reduction or recovery of growth within an individual tree ring sequence [22]. Accordingly, a growth suppression was a condition of growth retardation in a stressed tree [22]. Pollarding years appeared anatomically as abrupt and sustained growth suppressions, in which the earlywood width is not altered the year "0" after pollarding (Fig. 1). However, in the years " +1 " and " +2 " after pollarding the widths of the earlywood and of the whole ring are the smallest, as it has been previously observed $[2,3]$. Nevertheless, total ring-width progressively increases after 3 to 4 years as a consequence of a gradual increase in latewood width (Fig. 1). The formula for percentage growth change, proposed by Nowacki and Abrams [33], was adapted
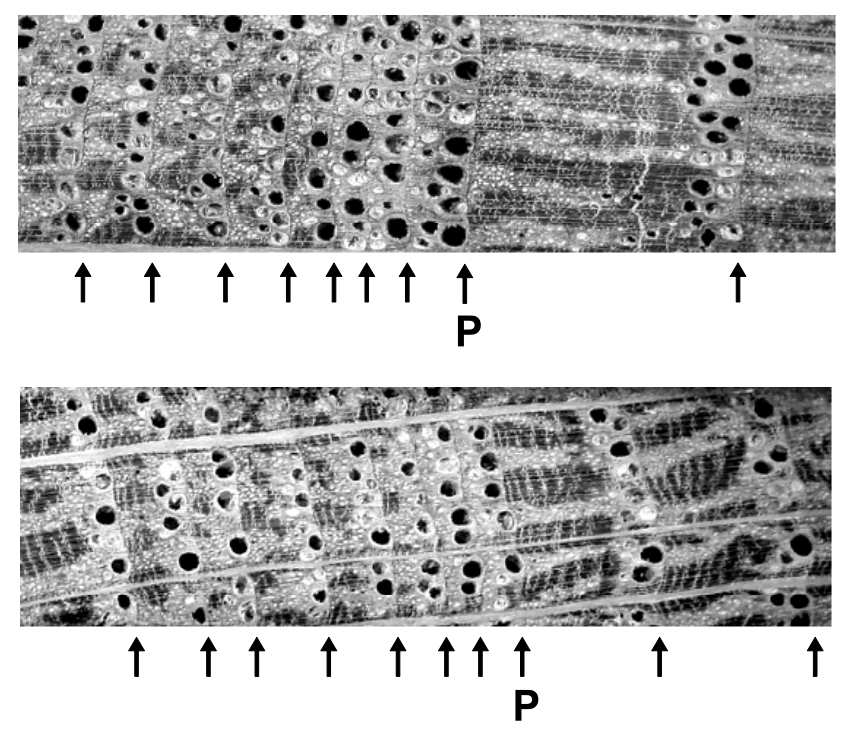

Figure 1. Tree-ring sequences $(\times 10)$ from two oaks in Tragamón showing growth suppressions due to pollarding $(\mathrm{P})$. Arrows indicate ring boundaries. Growth progress from right to left.

for the identification of abrupt and sustained growth releases and suppressions. To identify growth releases this formula was used

$$
P G C r=\frac{M_{2}-M_{1}}{M_{1}} \times 100
$$

while for suppressions it was used

$$
P G C s=\frac{M_{1}-M_{2}}{M_{2}} \times 100
$$

where $P G C r$ and $P G C s$ are the percentage growth change for releases and suppressions, respectively, and $M_{1}$ and $M_{2}$ are the preceding and subsequent 5-year ring-width means. A 5-year period was applied to the calculation of $P G C$ for greater precision, even though intervals of 6 and 7 years between successive cuts have previously been discovered on individual pollards $[16,36,41]$. Individual $P G C r$ and $P G C s$ chronologies were calculated by applying both formulae to the individual tree-ring series.

Based on previous criteria for the recognition of disturbance signals in tree-rings [1,27], two thresholds were employed to quantify the magnitude of growth changes. A moderate release, or suppression, was defined as a respective growth increase, or decrease, between 100 and $199 \%$. A major release, or suppression, was defined as a respective growth increase, or decrease, $\geq 200 \%$. Moderate and major growth releases and suppressions were separately compiled for mature and old-growth oaks on an annual basis. A year with a suppression event, indicative of tree pollarding, was considered as those in which at least one major suppression and/or two moderate suppressions had occurred within $\mathrm{a} \pm 1$ year interval. The frequency of event-occurrence was computed as the mean number of releases and suppressions per year, calculated in 10 -year intervals lagged by one year. To identify the spatial patterns of tree pollarding, stem maps of those trees that showed growth suppressions in significant pollarding episodes were plotted. The mean length of suppression intervals, and the mean number of suppressions per tree, were calculated and compared for both mature and old-growth oaks. Mean pollarding intervals, and the mean numbers of suppressions per year, were calculated in 50-year periods. Actual correlation between the mean frequencies of releases and suppressions, and the maximum correlation between those lagged for up to 15 years, were also calculated. 
Table I. Mean distances (m) between target trees and their nearest neighbours belonging to equal or different age class, and deviations (Dev.) from mean distances expected under the hypothesis of random arrangement of ages among oak stems. A significant negative deviation indicates aggregation of similarly aged trees, and a significant positive deviation indicates segregation between differently aged trees. $N$ : number of target trees.

\begin{tabular}{|c|c|c|c|c|c|c|c|c|c|}
\hline \multirow{2}{*}{ Age class (yr) } & \multirow{2}{*}{$N$} & \multicolumn{2}{|c|}{$<50$} & \multicolumn{2}{|c|}{$200-299$} & \multicolumn{2}{|c|}{$300-399$} & \multicolumn{2}{|c|}{$400-499$} \\
\hline & & Mean & Dev. & Mean & Dev. & Mean & Dev. & Mean & Dev. \\
\hline$<50$ & 56 & 5.9 & $-7.9 * *$ & & & & & & \\
\hline $200-299$ & 74 & 39.0 & $25.3 * *$ & 9.3 & $-2.7 * *$ & & & & \\
\hline $300-399$ & 80 & 37.2 & $23.5 * *$ & 13.9 & 2.0 & 11.4 & -0.1 & & \\
\hline $400-499$ & 22 & 38.8 & $25.1 * *$ & 20.6 & $8.7^{*}$ & 12.6 & 1.1 & 25.1 & 2.2 \\
\hline
\end{tabular}

$* P<0.05 ; * * P<0.01$.

\section{RESULTS}

\subsection{Populations structure}

The majority of the oaks in Tragamón were old-growth hollow trees larger than $60 \mathrm{~cm}$ in diameter and older than 250 years, which showed descending distributions up to a maximum of some $180 \mathrm{~cm}$ and 500 years (Fig. 2). In Southern Tragamón, no trees smaller than $50 \mathrm{~cm}$ in diameter, and only two trees younger than 250 years, were found. In Northern Tragamón, however, trees smaller than $50 \mathrm{~cm}$ and younger than 50 years were abundant. On the other hand, in La Isla, oaks between 40 and $80 \mathrm{~cm}$ in diameter and between 150 and 200 years old were dominant. However, trees younger than 125, or older than 325 years, were not encountered (Fig. 2).

In Tragamón, oaks younger than 50 years, and those between 200-299, were significantly clumped $(P<0.01)$, indicating aggregation of similarly aged trees within these age classes (Tab. I). By contrast, mean nearest-neighbour distances between trees older than 300 years did not significantly differ from the distances expected under a random arrangement of tree ages. Oaks younger than 50 years showed significant spatial repulsion $(P<0.01)$ of all the other age classes, and those belonging to the 200-299 age-class showed significant repulsion $(P<0.05)$ of oaks between 400-499 years (Tab. I). All the other analyses concerning spatial relationships between different age classes were not statistically significant, indicating some independence among old-growth trees in Tragamón. The surface map of oak ages showed that trees aged 200-399 years dominated the major part of Tragamón (Fig. 3). Oaks younger than 50 years were confined to four small areas, as well as two large ones in Northern Tragamón. Trees older than 400 years were widely spaced throughout the park, being dominant locally in certain parts of Southern Tragamón (Fig. 3).

\subsection{Abrupt growth changes}

Mean age of the sampled mature oaks was 182 years, while for old-growth oaks it was 306 years, and their age ranges did not overlap (Tab. II). The percentage of moderate releases was greater than the percentage of major releases in mature as well as old-growth oaks, while the percentage of major suppressions was greater than the percentage of moderate suppressions overall.
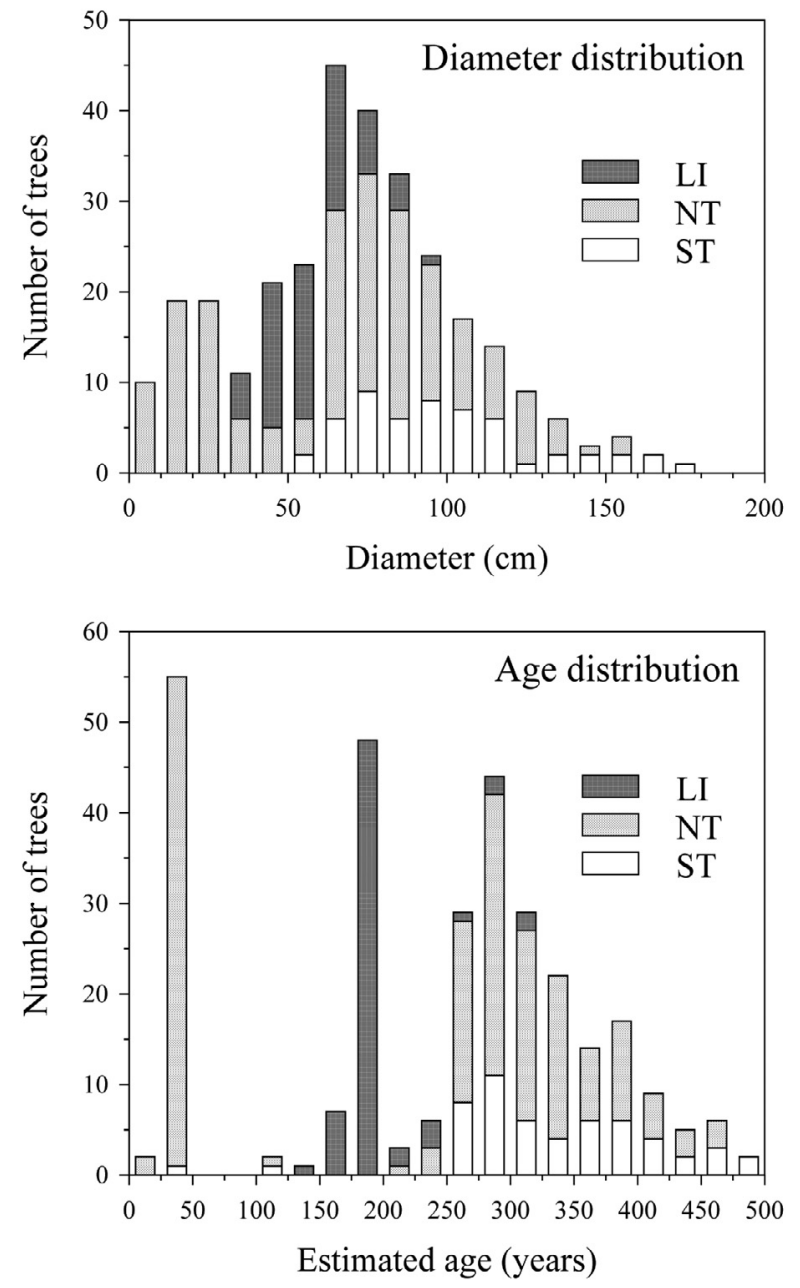

Figure 2. Diameter distribution, in 10-cm classes, and age distribution, in 25-year classes, of oak trees found in Southern Tragamón (ST), Northern Tragamón (NT) and La Isla (LI).

The number of pollarding events identified in old-growth oaks was greater than in mature oaks (Tab. II, Figs. 4 and 5). In mature oaks, the period with the greatest frequency of suppressions was $1825-1900$, and the years that showed the greatest number of growth suppressions were 1839, 1845, 1849, 
Table II. Number of trees sampled, age data, periods and characteristics of the tree-rings measured in Tragamón for mature and old-growth oaks.

\begin{tabular}{lcc}
\hline & Mature & Old-growth \\
\hline Number of sample trees & 52 & 57 \\
Mean age \pm SD (years) & $182 \pm 11$ & $306 \pm 54$ \\
Age range (years) & $138-206$ & $225-471$ \\
Period of record & $1775-2000$ & $1664-2000$ \\
Period of analysis & $1800-2000$ & $1725-2000$ \\
Number of measured rings & 8236 & 12299 \\
Rings with a moderate release (\%) & 0.83 & 1.59 \\
Rings with a major release (\%) & 0.24 & 0.48 \\
Rings with a moderate suppression (\%) & 0.59 & 1.14 \\
Rings with a major suppression (\%) & 0.75 & 1.26 \\
Number of pollarding events in the period of analysis & 17 & 47
\end{tabular}

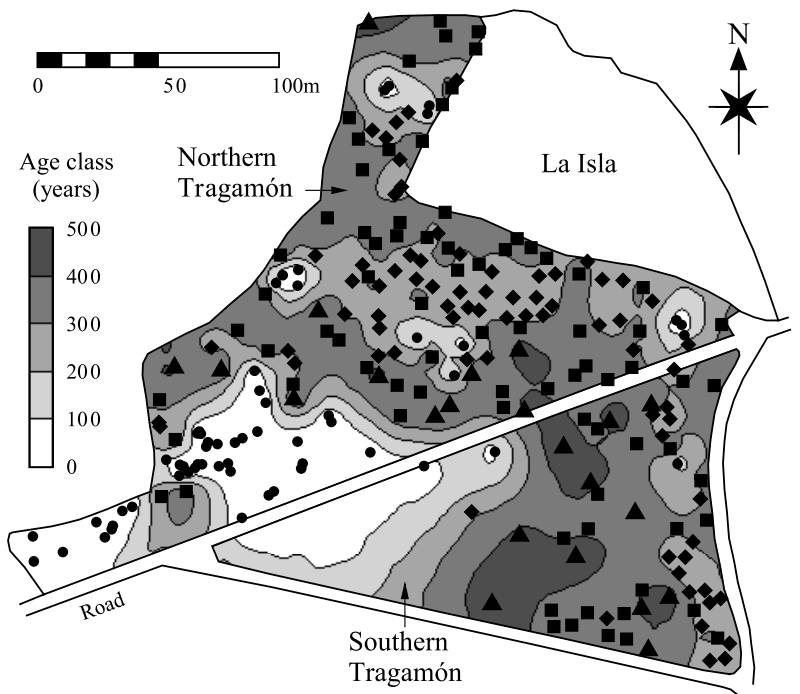

Figure 3. Surface map of Tragamón showing the location of oak stems and 100-year-age nested isolines. Symbols represent trees of different age: dots $<120$ years, diamonds $=200-299$ years, squares $=$ $300-399$ years, triangles $=400-499$ years.

1851, 1861 and 1917 (Fig. 4). Mean pollarding intervals for mature oaks ranged from 5.4 years in the period $1850-1899$ to 68 years in 1950-2000, and the mean number of suppressions per year decreased through time, being significantly greater in the 19th century than in the 20th $(H=63.13, D F=3, P<0.001$, Kruskal-Wallis test; Tab. III). In old-growth oaks, the period with the most frequent suppressions was 1750-1925, with the years $1756,1774,1806,1839,1859$ and 1905 showing a large number of growth suppressions (Fig. 5). Twenty-seven oldgrowth oaks showed growth suppression in 1905, which represent $52.9 \%$ of the sample size for this year. Mean pollarding intervals in old-growth oaks increased through time from 4.4 years in $1750-1799$ to 11.5 years in 1950-2000, while the mean number of suppressions per year significantly decreased,

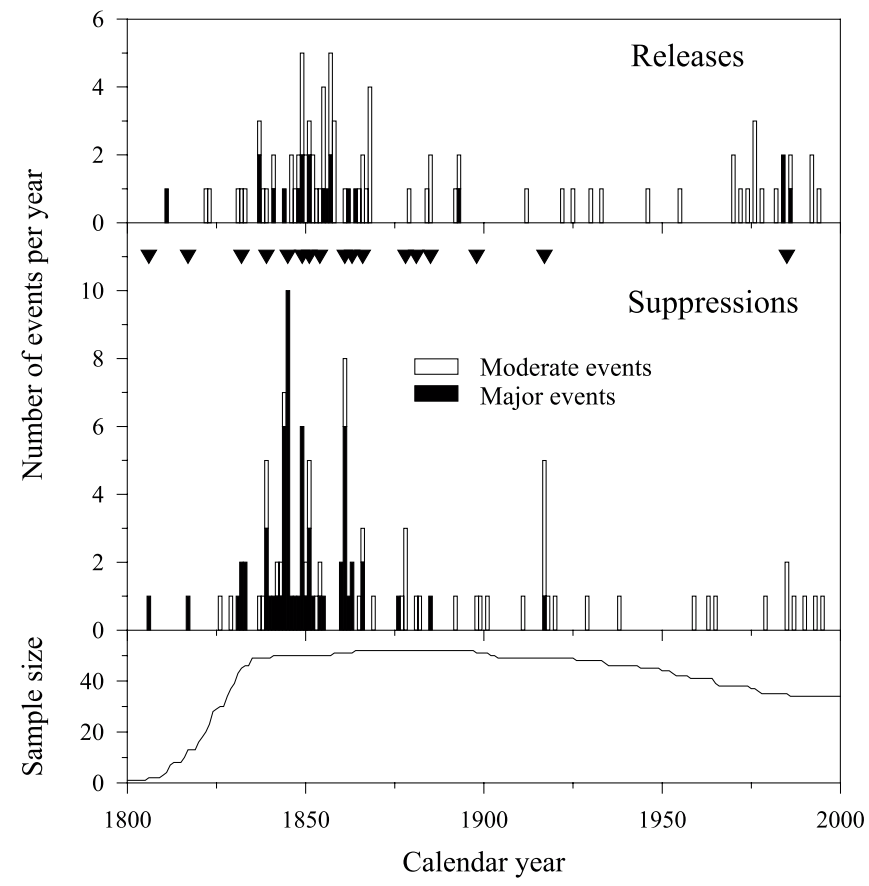

Figure 4. Number of mature oaks with moderate and major growth releases and suppressions, and the size of sample cores. Triangles represent years with at least one major suppression and/or two moderate suppressions within a \pm 1 year interval.

being over 1.50 in the period $1750-1849$, around 1.00 in 1850 1949 , and 0.32 in $1950-2000(H=108.14, D F=4, P<0.001$; Tab. III).

Peaks in the number of releases per year roughly coincided with peaks in the number of suppressions, although the formers were delayed by several years (Figs. 4 and 5). This delay became more evident when the mean numbers of releases and suppressions per year were plotted together (Fig. 6). Taking the complete period of analysis as a whole a maximum correlation between the frequency of suppressions and releases, when the 


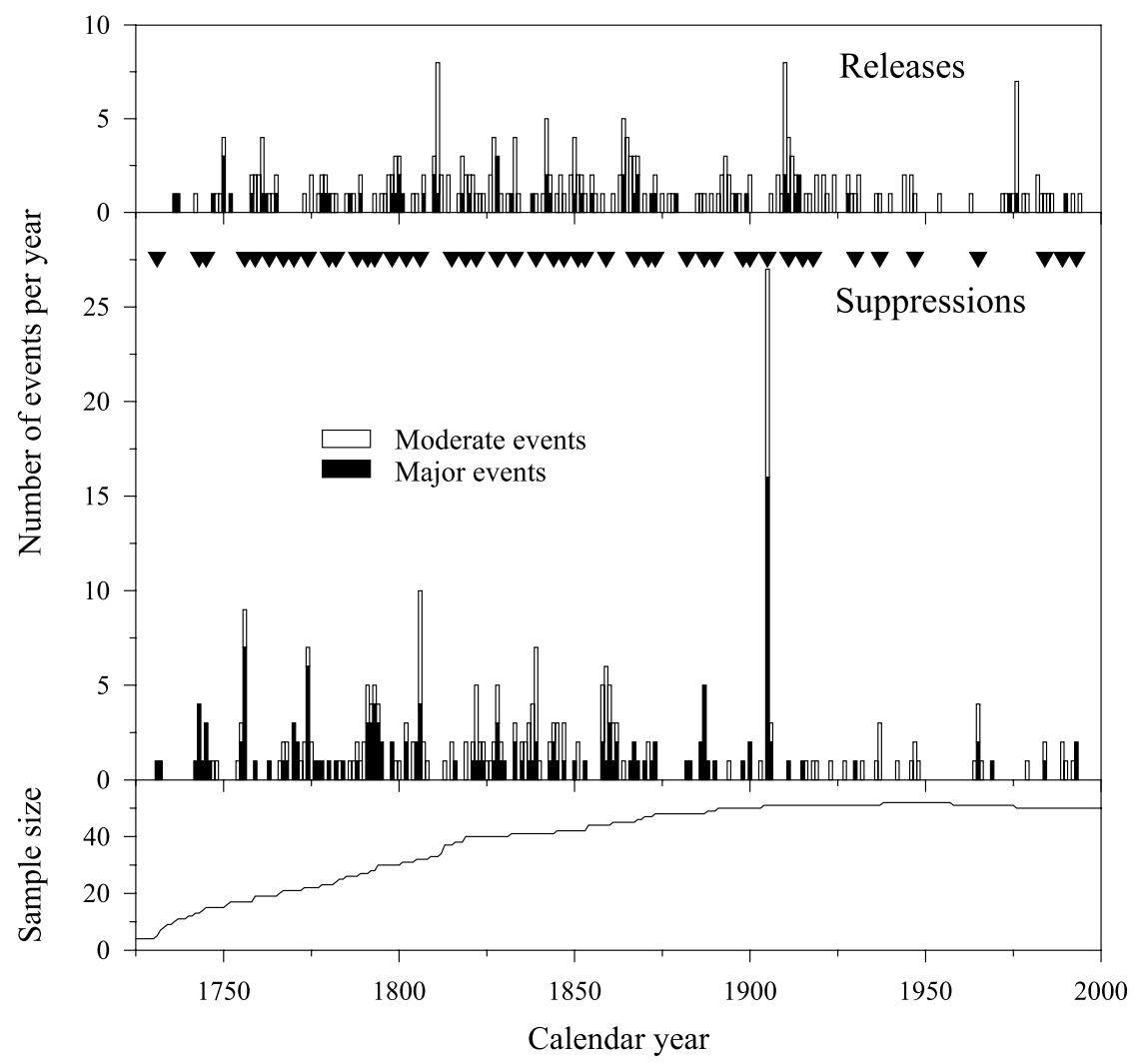

Figure 5. Number of old-growth oaks with moderate and major growth releases and suppressions, and the size of sample cores. Triangles represent years with at least one major suppression and/or two moderate suppressions within a \pm 1 year interval.

Table III. Mean pollarding intervals, mean number of suppressions per year and correlation between the frequencies of releases and suppressions in successive 50-year periods, for mature and old-growth oaks. Different letters in a row indicate significant differences according to a Kruskal-Wallis test at $P=0.05$.

\begin{tabular}{|c|c|c|c|c|c|}
\hline & $1750-1799$ & $1800-1849$ & $1850-1899$ & 1900-1949 & $1950-2000$ \\
\hline \multicolumn{6}{|l|}{ Mature } \\
\hline MPI (years) & & 8.6 & 5.4 & 19.0 & 68.0 \\
\hline Suppressions per year & & $0.97 \mathrm{a}$ & $0.80 \mathrm{a}$ & $0.23 b$ & $0.18 b$ \\
\hline Actual $R$ & & $0.928 * * *$ & $0.836 * * *$ & -0.032 & 0.195 \\
\hline Delay with maximum $R$ & & 6 & 5 & 10 & 0 \\
\hline Maximum $R$ & & $0.979 * * *$ & $0.873 * * *$ & $0.747 * * *$ & 0.195 \\
\hline \multicolumn{6}{|l|}{ Old-growth } \\
\hline MPI (years) & 4.4 & 4.9 & 5.1 & 6.1 & 11.5 \\
\hline Suppressions per year & $1.50 \mathrm{a}$ & $1.66 \mathrm{a}$ & $1.00 \mathrm{~b}$ & $0.98 b$ & $0.32 \mathrm{c}$ \\
\hline Actual $R$ & $-0.397 * *$ & $-0.572 * * *$ & $0.309^{*}$ & 0.148 & -0.179 \\
\hline Delay with maximum $R$ & 6 & 5 & 6 & 7 & 10 \\
\hline Maximum $R$ & $0.722 * * *$ & 0.229 & $0.926 * * *$ & $0.902 * * *$ & $0.379 * *$ \\
\hline
\end{tabular}

$* P<0.05 ; * * P<0.01 ; * * * P<0.001$.

frequency of releases was delayed by 6 years, was obtained $(R=$ $0.899, N=216, P<0.001$ in mature oaks, $R=0.768, N=276$ $P<0.001$ in old-growth oaks). This correlation was shown to be greater than that calculated without any delay $(R=0.749$ in mature oaks, $R=0.315$ in old-growth oaks). In fact, the delay with the maximum positive correlation varied among periods, 


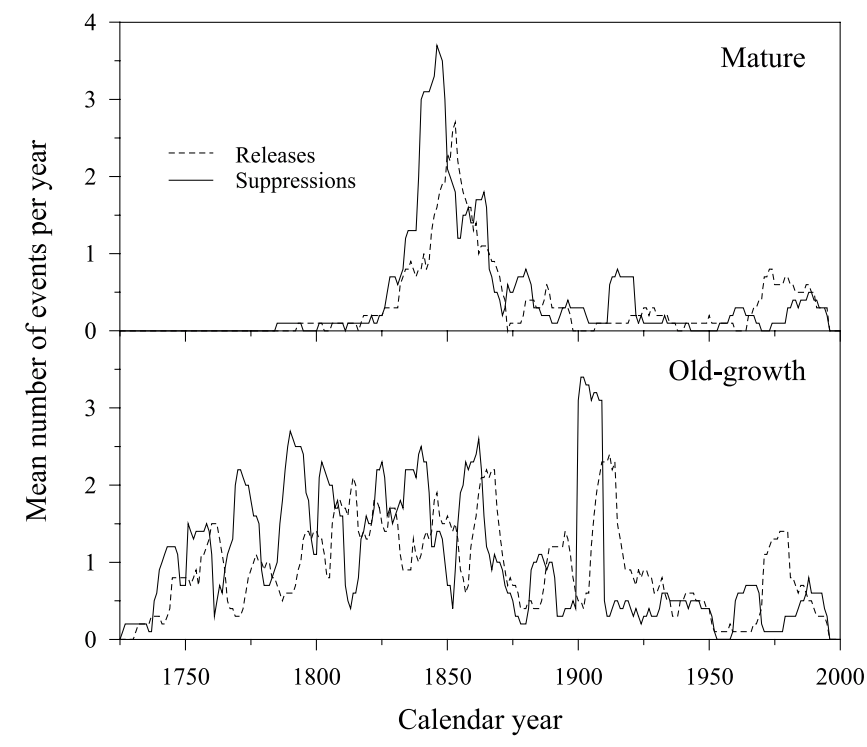

Figure 6. Temporal variation in the mean number of suppressions and releases per year, calculated in 10-year intervals, for mature and old-growth oaks.
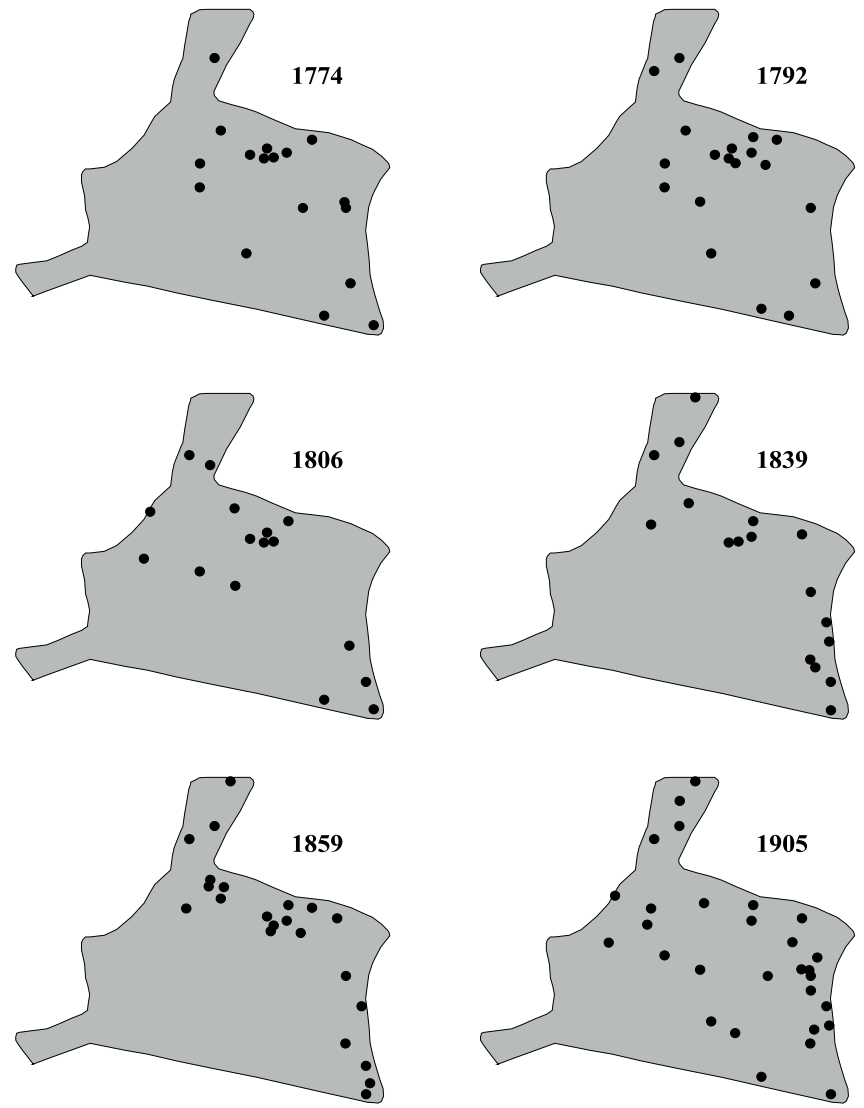

Figure 7. Spatial dispersion of old-growth oaks in Tragamón that showed synchronic abrupt growth suppressions in six relevant pollarding episodes.

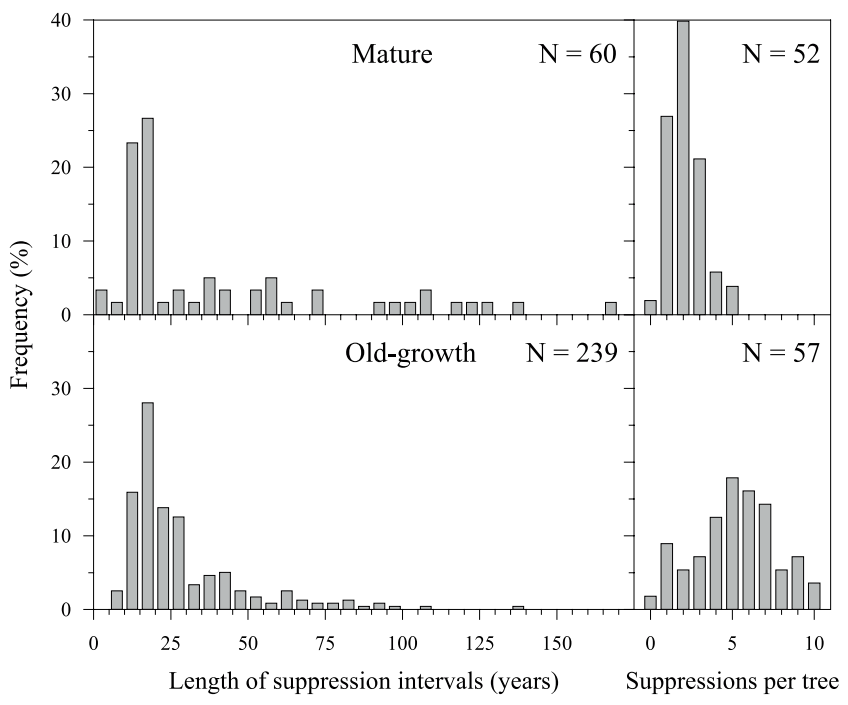

Figure 8. Percent frequency of the length of intervals between successive suppressions, and the number of suppressions per tree, in mature and old-growth oaks. N: number of suppression intervals and trees analysed.

ranging from between 5 to 10 years, with a greater frequency of 6 and 5 years in the period 1750-1899, and of 10 years in the 20th century (Tab. III).

The patterns of spatial distribution of old-growth oaks, which showed synchronic growth suppressions, differed for separate pollarding episodes (Fig. 7). Spatial dispersion of oaks pollarded in the years 1774 and 1792 showed similar patterns, as found in a specific group of trees in Northern Tragamón, as well as separate trees in Southern and Northern Tragamón. Oak pollarding in 1806 affected the southernmost extreme of Southern Tragamón, and the north-central area of Northern Tragamón. On the other hand, oaks pollarded in 1839 and 1859 showed similar distributions, particularly on the east border of Southern Tragamón and the north-east border of Northern Tragamón. Finally, the episode of massive growth reduction which occurred in 1905 affected trees more or less distanced throughout the complete range of old-growth oaks in Tragamón.

The length of suppression-intervals showed wide dispersion, with maximum lengths of up to 165 and 135 years in mature and old-growth oaks (Fig. 8). Intervals of 10-20 years between successive suppressions were more frequent in mature oaks, and in old-growth oaks intervals of 10-30 years predominated. However, the mean length of suppression intervals did not significantly differ between age classes (mean $\pm \mathrm{SD}=40.1 \pm$ 39.6 years in mature oaks, $28.1 \pm 19.9$ years in old-growth oaks, $U_{60,239}=7153.0, P=0.977$, Mann-Whitney test $)$. By contrast, the mean number of suppressions per tree was significantly greater in old-growth oaks (mean $\pm \mathrm{SD}=2.1 \pm 1.0$ in mature oaks, $5.2 \pm 2.4$ in old-growth oaks, $\left.U_{52,57}=431.0, P<0.001\right)$. Plots of frequency distribution indicated that mature oaks mainly showed between 1 and 3 suppressions, while in oldgrowths between 4 and 7 growth suppressions per tree were more frequent, with maximums of up to 5 and 10 suppressions in mature and old-growth oaks (Fig. 8). 


\section{DISCUSSION}

\subsection{Limitations of the results}

The results obtained should be interpreted with some caution due to certain accepted limitations in the materials studied and the analytical procedures used. Mean absolute errors, associated with the methods used to age young and mature oaks, can extend from 5 to 27 years [44]. What is more, errors in age estimates when these methods are applied to old-growth trees are unknown, as they have never been tested on oaks older than 300 years. It can be supposed that their accuracy probably decreased when bole diameter and tree age increased. In this particular study, accurate age estimation and past management reconstruction have been difficult to determine, since the majority of the trees in Tragamón showed some degree of bole decay. The loss of many radial growth sequences, through wood decay, prevented more accurate age estimation in old-growth trees, and probably reduced the signals of pollarding events.

However, the used method for management history reconstruction could tend to overestimate pollarding episodes, as all growth suppressions could not be a consequence of tree pollarding. Insect outbreaks that cause defoliation (e.g. Lymantria dispar L., Tortrix viridiana L. and Altica quercetorum Foundr.) or other defoliating outbreaks (oak mildew, Microsphaera alphitoides Griff. \& Maubl.) are very frequent in oaks and can lead to growth reductions similar to those caused by pollarding. Thus, the frequencies and intensities of pollarding episodes, as reconstructed in this work, might not exactly correspond to actual events. However, most of the growth suppressions were attributed to pollarding, as they showed an anatomical appearance typical of pollarding signals (Fig. 1) [2, 3]. The systematic coring of all trees without external evidence of bole decay, and the combination of moderate and strict criterions for event identification, should guarantee that the obtained reconstruction is largely reliable, as have other methods normally used to reconstruct disturbance regimes in temperate forests $[1,11,27,33$, $43,45]$.

\subsection{Establishment patterns}

Size and age distribution indicated a lack of oak regeneration in Southern Tragamón, while in Northern Tragamón trees younger than 50 years were abundant, indicating an hiatus in tree recruitment between 50 and 200 years ago. On the other hand, age distribution in La Isla was typically even-aged, with the majority of the trees being between 150-200 years old. These kinds of population structures are a consequence of alternating periods of light and heavy grazing pressure, in which seedlings may, or may not, have been established [17,37]. Over the past 50 years, oaks in Northern Tragamón have shown a regeneration pattern typical of this species. Pedunculate oak is a gap-obligate species that regenerates in open spaces and canopy gaps [45]. Accordingly, juvenile oaks were established away from old-growth trees in four gaps and in two large open areas (Fig. 3). Moreover, juveniles of oak and other minor woody species, such as Cornus sanguinea L., Euonymus europaeus L. and Salix atrocinerea Brot., were associated with populations of Rubus spp., Smilax aspera L. and Ulex gallii Planch. These spiny species, along with the heathers Erica vagans L. and Daboecia cantabrica (Huds.) C. Koch, could have played the role of nurse-plants which encouraged oak regeneration by protecting seedlings and young shoots from herbivore damage, such as grazing and trampling, as has been confirmed for other oak species [4, 12], and also for pedunculate oak [24]. The absence of any recent regeneration in Southern Tragamón could be interpreted as a lack of safe sites appropriate for oak establishment, this being the result of past over-grazing and, more recently, of lawn maintenance labour and trampling by the public.

The spatial structure of tree ages is an indicator of whether tree establishment has occurred either randomly or in evenaged patches. In the former pattern, neighbouring individuals will not necessarily be of a similar age, while in the latter strong similarities between the ages of neighbouring trees is to be expected [7, 28]. In Tragamón, oak recruitment occurred in even-aged clumps, spatially segregated from adult trees. This pattern was evident in trees younger than 50 years, and also in trees in the 200-299 year class which displayed a clumped pattern and a spatial segregation from veteran oaks, those older than 400 years (Tab. I). This result suggests that a former canopy of adult trees could have influenced the establishment of trees aged between 200-299 years. However, this pattern does not correspond with the normal distribution of mature trees in a natural forest because density-dependent mortality generally produces a transformation of the initial clumped pattern into either a random or regular distribution [49]. A consequence of tree pollarding is a prolongation of the life span. This is because the restriction of crown development delays the stage at which the demand for water and nutrients begins to outstrip the ability of trees to increase their absorptive root area [26]. In both Southern and Northern Tragamón, prolonged lifetimes in pollarded trees can explain the preservation of the initial clumped pattern in those oaks belonging to the 200-299 age class. In certain sectors of both areas, oaks between 200-399 years proved to be roughly aligned, suggesting that several groups of trees could have been planted. On the other hand, a random pattern should be expected for old-growth oaks due to the cumulative effects of recurrent pollarding and to the effect of ageing on tree survival $[6,41]$. This expectation was confirmed in this work for trees older than 300 years, but the sparse spatial distribution exhibited by such trees prevented any more substantial conclusions, relative to establishment patterns, from being reached.

\subsection{Evidence of management history}

Old-growth trees showed more growth suppressions and were more frequently pollarded than mature trees. Examination of pollarding signals compiled for Tragamón and La Isla (Figs. 4 and 5) revealed that several dates of growth suppression coincided in many oaks, independent of their ages. This happened in 1806, 1832-1833, 1839, 1844-1845, 1851, 18531854, 1866-1867, 1881-1882, 1898, 1917-1918 and 19841985 , in which suppressions were found on mature and oldgrowth trees. However, many pollarding signals were only found in old-growth oaks, especially those registered prior to 1800 , in which the mature trees were not pollarded yet. The spatial distribution of pollarding signals found in ring-widths revealed that particular patterns of tree selection can be identified in successive cutting turns (Fig. 7). Small groups of trees, 
along with several scattered trees, were pollarded in each turn, with the exception of 1905, in which a generalised reduction of growth was detected. This procedure is not as typical as that previously described in certain historical documents, in which woodland sections were pollarded in succession, following a regular cycle [6]. Probably, many trees to be pollarded in each cutting turn were selected by following a previously established scheme, but many of them, even the majority, could have been selected to maximise the amount of useable branch-wood, independent of the time that had elapsed since their last cut.

Many mature oaks in La Isla showed only one, two or three pollarding signals, while the majority of old-growth oaks found in Tragamón and La Isla showed between four to seven (Fig. 8). This could be because of the shorter life-span of mature trees, but it could also be a consequence of the different ownership of Tragamón and La Isla up to recent times, which determined different management systems for old-growth and mature trees. The majority of the sampled old-growths were found in Tragamón, which was a public common over past centuries and up to the 1990s. By contrast, all the mature trees were found in $\mathrm{La}$ Isla, an area which was acquired by a private landowner in the 19th century, and since that time has not been as intensively exploited as Tragamón. Probably, many mature trees in La Isla were shredded or trimmed instead of pollarded, as deduced by its aspect of maiden trees [38]. However, in mature as well as old-growth oaks, the mean pollarding interval consistently increased over time, and the mean number of suppressions per year decreased, both of which indicate a change in management system. Frequency and intensity of suppressions has decreased, particularly since 1917 in mature trees, and since 1905 in oldgrowths (Figs. 4 and 5). The loss of the pollarding practice, especially during the 20th century, could cause the collapse of many old-growth pollards, because of the accumulation of weight on severely decomposed trunks [41].

According to the findings obtained in this study, a delay of growth releases with respect to growth suppressions was evident (Fig. 6 and Tab. III). This delay was of 5-6 years prior to 1900 , in which both mature and old-growth oaks were actively managed, but varied from 0 to 10 years in the 20th century, as a consequence of a modification in the practice of pollarding. The growth releases which showed a characteristic delay of 56 years were of two different types: releases that resulted from growth recovery after pollarding in the same tree, and releases that were a consequence of growing space being released in the canopy when neighbouring trees were pollarded. Both types occurred principally prior to 1900. By contrast, from 1900 onwards, releases unrelated to growth-suppressions, which were a consequence of growing space released when neighbouring trees died, were also discovered. In these latter cases, any delay that might be expected as a response of tree growth to the release of growing space, fluctuated according to a combination of separate factors (tree age and canopy position, health status of the tree, competition for resources, climatic restrictions, disturbances, and chance [27, 33]). Overall, very little comparative information on past management practices in pollarded woodlands was available, other than the sporadic dating of pollarding signals based on tree-ring counting in single trees [6, $36,41]$. Also, no documentary evidence that supplemented the reconstructed management history in Tragamón was found. However, this work constitutes an innovative approach, which demonstrates the usefulness of dendroecological techniques in reconstructing past establishment patterns and historical management practices in old-growth pollarded woodlands.

\section{CONCLUSION}

There is vast potential for obtaining the history of long-term management systems through radial-growth analysis in many pollarded woodlands in Europe, which represent our best material to gain knowledge about traditional management practices. However, this availability may be particularly short-lived for old-growth pollards, which are continuously succumbing for a variety of reasons $[23,41]$. Many threats, which are in common with other European pollarded woodlands, were discovered in Tragamón. Because of the uncertainty of their future, the study of existing old-growth pollarded woodlands should be among the highest priorities for researchers in dendrochronology. Nonetheless, the coupled study of oak establishment dates and tree-ring widths revealed that historical patterns of tree regeneration and woodland management can be reasonably reproduced. The approach used in this study represents a significant contribution in the field of dendroecology, and should have broad application to a wide range of pollarded woodland types. They let us not forget that the documentation of past management systems is paramount in the understanding of how present-day pollarded woodlands developed over recent histories, and how they might alter in the future.

Acknowledgements: The author thanks Juan Luis Menéndez and Francisco Javier Suárez for field assistance, Juan Carlos Martínez for providing useful information on the recent history of Tragamón, and Kenneth McKenney for correcting the English manuscript. The Ayuntamiento de Gijón and the Dirección General de Recursos Naturales y Protección Ambiental del Principado de Asturias gave permission for taking the cores. This research was supported by the Consejería de Medio Ambiente del Principado de Asturias (SV-PA-00-01).

\section{REFERENCES}

[1] Abrams M.D., Orwig D.A., DeMeo T.E., Dendroecological analysis of successional dynamics for a presettlement-origin white-pinemixed-oak forest in the southern Appalachians, USA, J. Ecol. 83 (1995) 123-133.

[2] Bernard V., Autour du moulin carolingien de Belle-Église (Oise): éléments de techniques de charpenterie hydraulique, in: Beck P. (Ed.), Actes du VI ${ }^{\mathrm{e}}$ Congrès International d'Archéologie Médiévale: L'innovation technique au Moyen âge, Errance, Paris, 1997, pp. 77-80.

[3] Bernard V., Renaudin S., Marguerie D., Evidence of trimmed oaks (Quercus sp.) in north western France during the early Middle Ages (9th-11th century A.D.), in: 6th International Conference on Dendrochronology, Quebec, 2002, pp. 15-17.

[4] Callaway R.M., Effect of shrubs on recruitment of Quercus douglasii and Quercus lobata in California, Ecology 73 (1992) 21182128.

[5] Cherubini P., Piussi P, Schweingruber F.H., Spatiotemporal growth dynamics and disturbances in a subalpine spruce forest in the Alps: a dendroecological reconstruction, Can. J. For. Res. 26 (1996) 9911001.

[6] Dagley J., Burman P., The management of the pollards of Epping Forest: its history and revival, in: Read H.J. (Ed.), Pollard and vete- 
ran tree management, II, Corporation of London, Burnham Beeches, 1996, pp. 29-41.

[7] Duncan R.P., Stewart G.H., The temporal and spatial analysis of tree age distributions, Can. J. For. Res. 21 (1991) 1703-1710.

[8] Ellenberg H., Vegetation ecology of Central Europe, Cambridge University Press, Cambridge, 1988.

[9] Freléchoux F., Buttler A., Gillet F., Gobat J.-M., Schweingruber F.H., Succession from bog pine (Pinus uncinata var. rotundata) to Norway spruce (Picea abies) stands in relation to anthropic factors in Les Saignolis bog, Jura Mountains, Switzerland, Ann. For. Sci. 60 (2003) 1-10.

[10] Fritts H.C., Swetnam T.W., Dendroecology: a tool for evaluating variations in past and present forest environments, Adv. Ecol. Res. 19 (1989) 111-188.

[11] Glitzenstein J.S., Harcombe P.A., Streng D.R., Disturbance, succession, and maintenance of species diversity in an east Texas forest, Ecol. Monogr. 56 (1986) 243-258.

[12] Gómez J.M., García D., Zamora R., Impact of vertebrate acorn- and seedling-predators on a Mediterranean Quercus pyrenaica forest, For. Ecol. Manage. 180 (2003) 125-134.

[13] Guibal F., Bernard V., Approche dendrochronologique de l'évolution récente du système bocager armoricain, in: Richard H., Vignot A. (Eds.), Équilibres et ruptures dans les écosystèmes durant les 20 derniers millénaires: durabilité et mutation, Presses Universitaires Franc-Comtoises, Besançon, 2002, pp. 463-471.

[14] Guitián F., Muñoz M., Carballas T., Alberto F., Suelos Naturales de Asturias, CSIC, Instituto de Investigaciones Agrobiológicas de Galicia, Santiago de Compostela, 1985.

[15] Guyette R.P., Spetich M.A., Fire history of oak-pine forests in the Lower Boston Mountains, Arkansas, USA, For. Ecol. Manage. 180 (2003) 463-474.

[16] Haas J.-N., Schweingruber F.H., Wood anatomical evidence of pollarding in ash stems from the Valais, Switzerland, Dendrochronologia 11 (1994) 35-43.

[17] Harding P.T., Wall T. (Eds.), Moccas: an English deer park, Centre for Ecology and Hydrology, English Nature, Peterborough, 2000.

[18] Holmes R.L., Computer-assisted quality control in tree-ring dating and measurement, Tree-Ring Bull. 43 (1983) 69-78.

[19] Hupp C.R., Simon A., Bank accretion and the development of vegetated depositional surfaces along modified alluvial channels, Geomorphology 4 (1991) 111-124.

[20] Jacoby G.C., Application of tree ring analysis to paleoseismology, Rev. Geophys. 35 (1997) 109-124.

[21] Jardon Y., Filion L., Cloutier C., Tree-ring evidence for endemicity of the larch sawfly in North America, Can. J. For. Res. 24 (1994) 742-747.

[22] Kaennel M., Schweingruber F.H., Multilingual glossary of dendrochronology: terms and definitions in English, German, French, Spanish, Italian, Portuguese, and Russian, Swiss Federal Institute for Forest, Snow and Landscape Research, Haupt, 1995.

[23] Kirby K.J., Thomas R.C., Key R.S., McLean I.F.G., Hodgetts N., Pasture-woodland and its conservation in Britain, Biol. J. Linn. Soc. 56 (1995) 135-153.

[24] Kuiters A.T., Slim P.A., Tree colonisation of abandoned arable land after 27 years of horse-grazing: the role of bramble as a facilitator of oak wood regeneration, For. Ecol. Manage. 181 (2003) 239-251.

[25] Legendre P., Fortin M.-J., Spatial pattern and ecological analysis, Vegetatio 80 (1989) 107-138.

[26] Lonsdale D., Pollarding success or failure: some principles to consider, in: Read H.J. (Ed.), Pollard and Veteran Tree Management II, Corporation of London, Burnham Beeches, 1996, pp. 100-104.

[27] Lorimer C.G., Frelich L.E., A methodology for estimating canopy disturbance frequency and intensity in dense temperate forests, Can. J. For. Res. 19 (1989) 651-663.

[28] Lusk C.H., Smith B., Life history differences and tree species coexistence in an old-growth New Zealand rain forest, Ecology 79 (1998) 795-806.
[29] Manly B.F.J., Randomization, Bootstrap and Monte Carlo, Methods in Biology, Chapman \& Hall, London, 1997.

[30] Marin P., Filion L., Recent dynamics of subarctic dunes as determined by tree-ring analysis of white spruce, Hudson Bay, Québec, Quat. Res. 38 (1992) 316-330.

[31] Moe B., Botnen A., A quantitative study of the epiphytic vegetation on pollarded trunks of Fraxinus excelsior at Havrå, Osterøy, western Norway, Plant Ecol. 129 (1997) 157-177.

[32] Motta R., Garbarino F., Stand history and its consequences for the present and future dynamic in two silver fir (Abies alba Mill.) stands in the high Pesio Valley (Piedmont, Italy), Ann. For. Sci. 60 (2003) 361-370.

[33] Nowacki G.J., Abrams M.D., Radial-growth averaging criteria for reconstructing disturbance histories from presettlement-origin oaks, Ecol. Monogr. 67 (1997) 225-249.

[34] Payette S., Filion L., Delwaide A., Disturbance regime of a cold temperate forest as deduced from tree-ring patterns: The Tantaré ecological reserve, Quebec, Can. J. For. Res. 20 (1990) 1228-1241.

[35] Peterken G.F., Natural Woodland: Ecology and Conservation in Northern Temperate Regions, Cambridge University Press, Cambridge, 1996.

[36] Pilcher J.R., Dendrochronological insights into past oak growth, Ann. Sci. For. 53 (1996) 663-670.

[37] Pulido F.J., Díaz M., Hidalgo de Trucios S.J., Size structure and regeneration of Spanish holm oak Quercus ilex forests and dehesas: effects of agroforestry use on their long-term sustainability, For Ecol. Manage. 146 (2001) 1-13.

[38] Rackam O., Ancient woodland: its history, vegetation and uses in England, E. Arnold, London, 1980.

[39] Ranius T., Influence of stand size and quality of tree hollows on saproxylic beetles in Sweden, Biol. Conserv. 103 (2002) 85-91.

[40] Rasmussen P., Pollarding of trees in the Neolithic: often presumed - difficult to prove, in: Robinson D.E. (Ed.), Experimentation and Reconstruction in Environmental Archaeology, Oxbow Books, Roskilde, 1990, pp. 77-98.

[41] Read H., Veteran trees: a guide to good management, English Nature, The Countryside Agency and English Heritage, Peterborough, 2000.

[42] Rodwell J.S. (Ed.), British plant communities, Volume 1: Woodlands and scrub, Cambridge University Press, Cambridge, 1991.

[43] Rozas V., Detecting the impact of climate and disturbances on treerings of Fagus sylvatica L. and Quercus robur L. in a lowland forest in Cantabria, Northern Spain, Ann. For. Sci. 58 (2001) 237-251.

[44] Rozas V., Tree age estimates in Fagus sylvatica and Quercus robur: testing previous and improved methods, Plant Ecol. 167 (2003) 193-212.

[45] Rozas V., Regeneration patterns, dendroecology, and forest-use history in an old-growth beech-oak lowland forest in Northern Spain, For. Ecol. Manage. 182 (2003) 175-194.

[46] Stahle D.W., VanArsdale R.B., Cleaveland M.K., Tectonic signal in baldcypress trees at Reelfoot Lake, Tennessee, Seism. Res. Lett. 63 (1992) 439-447.

[47] Stokes M.A., Smiley T.L., An introduction to tree-ring dating, University of Chicago Press, Chicago, 1968.

[48] Swetnam T.W., Lynch A.M., Multicentury, regional-scale patterns of western spruce budworm outbreaks, Ecol. Monogr. 63 (1993) $399-424$

[49] Szwagrzyk J., Czerwczak M., Spatial patterns of trees in natural forests of East-Central Europe, J. Veg. Sci. 4 (1993) 469-476.

[50] Upton G.J.G., Fingleton B., Spatial data analysis by example, Volume I. Point pattern and quantitative data, Wiley \& Sons, Chichester, 1985

[51] Veblen T.T., Kitzberger T., Villalba R., Donnegan J., Fire history in Northern Patagonia: the roles of humans and climatic variation, Ecol. Monogr. 69 (1999) 47-67. 